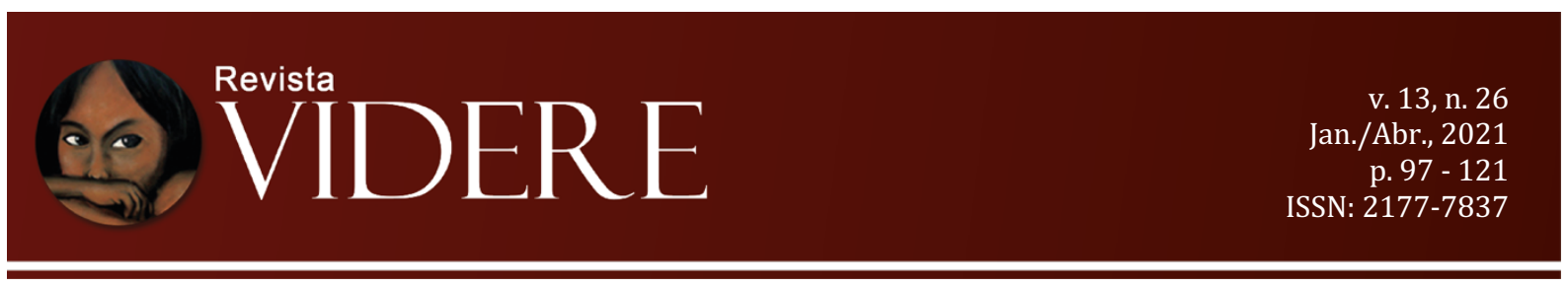

\title{
CONFLITOS SOCIOAMBIENTAIS E DISPUTAS SOBRE AS TERRAS INDÍGENAS ${ }^{1}$
}

\author{
SOCIO-ENVIRONMENTAL CONFLICTS AND DISPUTES ON \\ INDIGENOUS LANDS
}

\author{
CONFLICTOS SOCIOAMBIENTALES Y DISPUTAS \\ POR TIERRAS INDÍGENAS
}

\author{
Renata Brockelt Giacometti \\ Doutoranda \\ UFPR \\ E-mail: renatabgiacometti@gmail.com \\ ORCID: 0000-0001-8498-3726
}

\begin{abstract}
Dimas Floriani
Pós-Doutor

UFPR

E-mail: dimas@casla.com.br; floriani@ufpr.br

ORCID: 0000-0002-8834-8225
\end{abstract}

\begin{abstract}
Resumo: O sistema de mercado presente na sociedade mundial tem apresentado importantes retrocessos sobre as dinâmicas ambientais nos últimos anos, sendo perceptível os interesses na obtenção de lucros na utilização de áreas atualmente preservadas. Tal questão impacta na temática indígena, sobre seus territórios. Deste modo, o presente trabalho traz um levantamento sobre os principais conflitos socioambientais ocorridos em terras indígenas, como base no Mapa de Conflitos Socioambientais da Fundação Oswaldo Cruz (FIOCRUZ, 2020a), destacando seus pontos críticos tanto para uma preservação ambiental quanto para a manutenção sociocultural daquelas populações. Ao final, são apresentadas algumas contradições existentes entre a racionalidade econômica e questões socioambientais, e como tal contradição repercute na desestruturação das políticas públicas socioambientais nos países periféricos. A importância da presente discussão encontra respaldo na contemporaneidade do tema, demonstrando, na prática, o impacto das políticas econômico-desenvolvimentistas sobre as terras indígenas.
\end{abstract}

Palavras-chave: Povos indígenas. terras indígenas. meio ambiente. capitalismo global. pensamento decolonial.

\footnotetext{
${ }^{1}$ Artigo apresentado no $11^{\circ}$ Seminário Nacional de Sociologia e Política - UFPR, em outubro de 2020, ocorrido em Curitiba/PR. A presente versão possui incorporações decorrentes dos debates ocorridos no citado evento.
} 
Abstract: The market system present in the world society, has presented important setbacks on the environmental dynamics in the last years, being perceptible the interests in obtaining profits in the use of currently preserved areas. Such matter impacts on the indigenous theme, uppon their territories. In this way, the present paper brings a survey on the main socio-environmental conflicts occurred in indigenous lands, based on the Map of Socio-environmental Conflicts of the Oswaldo Cruz Foundation (FIOCRUZ, 2020a), highlighting its critical points, both for environmental preservation and for socio-cultural maintenance of those populations. At it's end, we present some contradictions between economic rationality and socio-environmental issues, and how such contradictions have an impact on the crumbling of public socio-environmental policies in sorrounding countries. The importance of the present discussion is supported by the contemporary nature of the theme, demonstrating, in practice, the impact of economicdevelopmentalist policies on indigenous lands.

Keywords: Indigenous peoples. indigenous lands. environment. global capitalism. decolonial thinking.

Resumen: El sistema de mercado presente en la sociedad mundial ha presentado importantes retrocesos en la dinámica ambiental en los últimos años, siendo perceptible el interés en obtener ganancias en el uso de áreas actualmente preservadas. Tal pregunta impacta en el tema indígena, en sus territorios. Así, el presente trabajo proporciona un relevamiento de los principales conflictos socioambientales ocurridos en tierras indígenas, a partir del Mapa de Conflictos Socioambientales de la Fundación Oswaldo Cruz (FIOCRUZ, 2020a), destacando sus puntos críticos tanto para la preservación ambiental como para el mantenimiento sociocultural. de esas poblaciones. Al final, se presentan algunas contradicciones entre la racionalidad económica y la lógica socioambiental, y como tal contradicción repercute en la disrupción de las políticas públicas socioambientales en los países periféricos. La importancia de esta discusión se sustenta en el carácter contemporáneo del tema, demostrando, en la práctica, el impacto de las políticas económico-desarrollistas en las tierras indígenas.

Keywords: Pueblos indígenas. tierras indígenas. medio ambiente. capitalismo global. pensamiento decolonial.

\section{Introdução}

A dinâmica de mercado presente na sociedade mundial tem apresentado importantes entraves para uma agenda socioambiental ${ }^{2}$ nos últimos anos, demonstrando uma racionalidade econômica desconectada de questões socioambientais (RAWORTH, 2019, p. 18-19).

Tal racionalidade, acentuadamente presente na modernidade periférica, é decorrente de uma herança colonial e de uma crescente mercantilização da natureza, evidentes através da produção e da expansão do espaço do capital pelo neoextrativismo ${ }^{3}$, pelo agronegócio e pela

\footnotetext{
${ }^{2}$ Empregamos o termo 'socioambiental' para caracterizar a indissociabilidade entre os aspectos físicos dos ecossistemas e a dimensão sociocultural das populações nativas que interagem com eles.

${ }^{3}$ Neoextrativismo é compreendido, aqui, como a extração predatória vegetal (madeireiras), mineral (mineração) e animal (caça e contrabando de animais silvestres).
} 
apropriação dos territórios pertencentes aos povos indígenas e às populações tradicionais (FLORIANI, 2020, p. 298).

Para Quijano (2010), a herança colonial demonstra uma desarticulação das políticas públicas dos países periféricos, de maneira que estes se mantenham na contínua posição de colonizados. Neste sentido, a colonialidade de poder é algo que atravessa as sequelas deixadas pelo colonialismo, mas que é muito mais abrangente e complexa, uma vez que se estende até o presente, além de produzir efeitos de ordem cultural e que permite reproduzir a geopolítica da desigualdade histórica entre as nações.

Significa dizer que, ao invés do fortalecimento das leis socioambientais, observa-se uma desestruturação das conquistas ocorridas, gerando, em certa medida, uma mercantilização da natureza.

Neste contexto, Quijano (2010) explica que com a globalização ocorreu a criação de um novo padrão mundial de poder, especialmente com a criação de um mercado global oriundo da modernidade eurocêntrica (que hoje se amplia para os chamados países nórdicos). $\mathrm{O}$ surgimento deste novo padrão de poder, que gira em torno do capital e do mercado, segue uma lógica de dominação através da ideia de superioridade racial; o globo terrestre passa, assim, a ser separado por regiões, nas quais a raça tornou-se o primeiro critério fundamental para a classificação social da população mundial (QUIJANO, 2005, p. 118) .

Como consequência, o capitalismo apresenta uma nova estrutura de controle e de exploração do trabalho, ampliando a tradicional exploração do trabalho pelo capital para outros mecanismos de extração da riqueza das nações, aqui designados por neoextrativismo (SVAMPA, 2019; ESCOBAR, 2005; entre outros). E esta lógica existente faz com que os países colonizados sejam fornecedores de commodities, muitas vezes, flexibilizando a proteção socioambiental desejada.

O neoextrativismo apresenta-se, pois, como um revival do período primário exportador das economias periféricas, buscando justificar-se pela mundialização do mercado

\footnotetext{
${ }^{4}$ A questão do racismo reveste-se de uma complexidade e abrangência tal que não pode ser tratada de forma genérica e varia de situação em situação, tanto nos países capitalistas centrais quanto nos periféricos. Para uma diferenciação entre as manifestações vinculadas ao debate do racismo, verifica-se como Didier Fassin (JAIME e LIMA, 2011) se refere ao fenômeno: "Em primeiro lugar, vale a pena mencionar que as raças não existem. No entanto, é inegável que certas pessoas formulam discursos e conduzem ações como se elas existissem. Pode ser para rebaixar, humilhar, discriminar, separar, exterminar. Falamos nesse caso de racismo. Pode ser para designar, reivindicar, contar. Falamos então de racialização. Do ponto de vista analítico, como do ponto de vista moral, o racismo não representa um problema, pois sabemos que ele procede de uma inferiorização ou uma negação do outro racializado e geralmente concordamos em considerar que se trata de uma prática a ser condenada, inclusive nos tribunais. Já a racialização é mais problemática, ao mesmo tempo em uma perspectiva analítica (O que ela significa? O que nos permite dizer?) e moral (É ruim utilizar a linguagem racial? Como avaliar particularmente esta linguagem quando é utilizada por aqueles a quem se discrimina?)".
} 
que permite obter divisas para o país, cujas empresas multinacionais são majoritariamente de capital internacional. Seu efeito é predatório pois localizam-se em territórios indígenas com profundos impactos socioambientais, comprometendo os ecossistemas e o modo de vida cultural das populações locais (ABAD RESTREPO, 2018).

Assim, pensando na lógica de mercado, o preço de custo de qualquer mercadoria é resultado dos desembolsos prévios em matéria-prima, matérias auxiliares, infra-estrutura, maquinário, salários, dentre outros. A diferença entre esse preço de custo e o preço de venda constitui o lucro. Incorporar matérias de origem natural, sem preço, gera vantagem competitiva em relação aqueles que devem pagar pelas matérias-primas naturais. Como resultado, há a pilhagem dos recursos naturais dos biomas brasileiros (FOLADORI, 2001, p.173-175).

Note-se que atualmente no Brasil, além das áreas de preservação/conservação ambiental, as áreas nativas mais propensas a este tipo de neoextrativismo ilegal são as reservas indígenas ou terras indígenas em processo de demarcação.

O agronegócio, por sua vez, é marcado pela monocultura, a qual traz vantagem econômica para o produtor mas uma desvantagem para a sociedade, por gerar uma agricultura frágil e sujeita à flutuações climáticas e necessidade de agrotóxicos (comprovadamente tóxicos aos seres humanos) como forma de manter a alta produtividade e o lucro (FOLADORI, 2001, p. 176).

Para identificar os mecanismos de justificativa das políticas de Estado para esses casos, pode-se citar, como exemplo, o processo denominado "Revolução Verde" ocorrido na década de setenta quando algumas fundações iniciaram um discurso, a nível global, visando "acabar com a fome no mundo" (ALBERGONI; PELAEZ, 2007, p. 39). Este discurso, na prática, consubstanciou-se na venda de pacotes de insumos agrícolas aos países em desenvolvimento, visando o aumento de produção de alimentos. Como resultado, temos que o Brasil efetivamente tornou-se um “celeiro do mundo" (COMPRE RURAL, 2019), mantendo sua balança comercial positiva graças ao agronegócio (BRASIL, 2020b e SILVA, 2020).

É importante observar que, não obstante tal fala ter sido propagada por fundações sem fins lucrativos (notadamente a Fundação Rockefeller e a Fundação Ford), grandes empresas que se beneficiam com a venda de tais insumos continuam apresentando campanhas de valorização do agronegócio (MELO, 2018, p. 108-109).

Uma das grandes consequências negativas desta situação foi que ao invés de se desenvolverem métodos de produção de alimentos integrados com a natureza, dentre os quais cita-se os sistemas agroflorestais, a chamada "Revolução Verde" que colocou em risco tanto a sustentabilidade ambiental como também o equilíbrio econômico entre as partes 
(ALBERGONI; PELAEZ, 2007), fomentando uma devastação da natureza (SOUZA FILHO, 2015, p. 61).

Mas qual seria a relação entre a herança colonial e mercantilização da natureza com a apropriação dos territórios pertencentes aos povos indígenas? Considerando que a quantidade de terras e bens naturais são finitos (RAWORTH, 2019, p. 85), o discurso do mercado é no sentido de que quanto mais terras indígenas são demarcadas, menos espaço há para a expansão territorial do agronegócio e do neoextrativismo. Ou seja, os atuais ataques verificados contra os territórios indígenas, por parte do atual governo federal, seja através da flexibilização das regras de proteção e de fiscalização ambiental (LEITE, et. al, 2019 p. 177), seja através da omissão no atendimento diferenciado em relação à propagação do COVID-19 em um sistema de saúde já fragilizado (ROCHA, 2020, p. 2), têm sido alvo de contundentes críticas internacionais e do movimento indigenista brasileiro (Instituto Socioambiental, 2020b).

\section{Levantamento dos impactos socioambientais envolvendo povos indígenas}

A fim de verificar as ocorrências de conflitos nos quais os povos indígenas fazem parte, utilizou-se o levantamento de dados realizado pela Fundação Oswaldo Cruz (FIOCRUZ, 2020a), tendo como base o "Mapa de Conflitos Envolvendo Injustiças Ambientais e Saúde no Brasil", ou simplesmente "Mapa de Conflitos". Assim, foi possível sistematizar os principais conflitos socioambientais existentes no território brasileiro envolvendo as populações indígenas, em disputa com agentes públicos ou privados.

Este estudo partiu de uma pesquisa bibliográfica sobre os aspectos de desenvolvimento espacial e de acumulação de capital no Brasil, buscando compreender os conceitos de conflitos e (in)justiças socioambientais.

$\mathrm{Na}$ sequência, foi realizada a leitura de Porto; Pacheco; Leroy (2013), visando compreender a metodologia utilizada na construção do Mapa de Conflito, pela FIOCRUZ. É importante ressaltar que o citado Mapa possui uma constante e contínua atualização; deste modo, apesar de ter iniciado sua construção em 2009, encontra-se em permanente alteração. Quanto aos aspectos metodológicos, os dados constantes no Mapa de Conflitos são decorrentes da experiência dos autores e também de uma revisão bibliográfica; em outros termos, apesar de serem considerados relatórios etnográficos, por exemplo, quem efetivamente fez o lançamento das informações não foi à campo em cada uma das fichas descritas (PORTO; PACHECO; LEROY, 2013). 
Por fim, foi realizada uma análise dos dados constantes no Mapa de Conflitos (FIOCRUZ, 2020a), com um olhar crítico não apenas sobre os dados absolutos, mas também sobre a forma como o mapeamento foi elaborado, resultando num entendimento mais abrangente do estudo que ora se apresenta. Nas fichas em que a informação era dúbia, foram realizadas consultas nas fontes de pesquisa citadas e/ou em outros estudos correlatos à temática apresentada, visando uma compreensão mais abrangente sobre o conflito em questão.

A metodologia deste estudo, portanto, foi dividida em três etapas relevantes: primeiro, compreender os conceitos de conflitos e (in)justiças socioambientais; em seguida, compreender a forma como ocorreu a sistematização de dados no "Mapa de Conflitos Envolvendo Injustiça Ambiental e Saúde no Brasil” (FIOCRUZ, 2020a), através da leitura de Porto, Pacheco e Leroy (2013); e por fim, como base no mapa on-line, sistematizar as informações, através de triagem, padronização e análise dos dados coletados.

O objetivo geral da pesquisa realizada é analisar quais são os principais conflitos socioambientais existentes no território brasileiro, identificando os responsáveis ou causadores (enquanto agentes públicos ou privados), envolvendo os povos indígenas e suas terras. A análise parte de um panorama nacional, mas abrange também os impactos ocorridos em cada uma das macrorregiões brasileiras (Norte, Nordeste, Centro-oeste, Sudeste e Sul).

Para Porto, Pacheco e Leroy (2013, p. 35), o Mapa de Conflitos tem como finalidade tornar pública as vozes existentes no Brasil, frequentemente discriminadas e invisibilizadas, que clamam por justiça. Deste modo, é possível monitorar ações e projetos que atendam às demandas das populações por justiça, saúde e cidadania, sendo um instrumento em contínua análise e aperfeiçoamento (PORTO; PACHECO; LEROY, 2013, p. 43).

A seleção dos casos constantes no citado Mapa considerou situações emblemáticas de transformações no território brasileiro decorrentes de circunstâncias que não considera os indivíduos nem tão pouco o meio ambiente ali existentes. Destaca-se, também, que as informações constantes na plataforma on-line são resultado tanto das experiências dos autores daquele Mapa quanto da sintetização de dados existentes em relatórios e artigos desenvolvidos por entidades, ONGs e instituições parceiras, inclusive grupos acadêmicos, instituições governamentais, Ministérios Públicos ou órgãos do judiciário. (PORTO; PACHECO; LEROY, 2013).

A triagem de dados, propriamente dita, ocorreu a partir das fichas e demais informações inseridas da plataforma on-line do "Mapa de Conflitos e Injustiça Ambiental em Saúde no Brasil”. O levantamento de dados ocorreu nos meses de julho e agosto de 2019, tendo como principal filtro a seleção das populações indígenas. Deste modo, dos 605 conflitos 
inicialmente encontrados, $177(20 \%)$ estariam relacionados diretamente com os povos indígenas, em território brasileiro.

Estes dados foram manualmente copiados e exportados para um editor de planilhas, Microsoft Excel ${ }^{\circledR}$, destacando "Localidade" (estado brasileiro), "Município", "Atividade geradora de conflito", "Povos indígenas atingidos", "Terra indígena atingida", "Outras populações atingidas", "Impactos socioambientais", "Última atualização da ficha e Observações”. Nas planilhas, a categorização assumida para cada tipificação foi a mesma do site, visando manter o enquadramento dos dados feito pela equipe que elaborou o Mapa de Conflitos.

Após uma leitura minuciosa das informações de cada ficha de conflito, percebeu-se que dos 177 conflitos inicialmente levantados pelo site, 166 conflitos indicavam objetivamente os povos indígenas atingidos. Como exemplo, cita-se um caso ocorrido em Rondônia, Município de Cacoal, tendo como Atividade geradora do conflito a Pecuária. Esta ficha, atualizada em 2009, indica como Impactos socioambientais: "Desmatamento e/ou queimada, Mudanças climáticas, Poluição atmosférica”. Assim, ainda que existam populações indígenas atingidas por pecuária na região de Cacoal, objetivamente a ficha não indica qual a população indígena que está sofrendo tais impactos. Deste modo, para os gráficos elaborados, as fichas que apresentem semelhante omissão não foram consideradas. Diante de tal análise, dos 177 conflitos inicialmente levantados, foram considerados os 166 que objetivamente indicam qual a população indígena está envolvida na disputa.

Foram identificadas no Mapa de Conflitos 28 categorias de "Atividade geradora de conflito", conforme é possível visualizar na Tabela 1 abaixo. Note-se que as categorias aparecem conjugadas numa mesma ficha, ou seja, um mesmo conflito pode ter várias atividades que geram tal ocorrência.

Além destas categorias, observou-se que a falta de "Atuação de entidades governamentais" gerava, como consequência, uma omissão estatal no atendimento às condições básicas de saúde para as populações indígenas. Entretanto, pela descrição detalhada das fichas, observou-se que a principal reivindicação constante na descrição era exatamente a falta de atendimento à saúde indígena. Como exemplo, cita-se a contenda catalogada tendo como local de ocorrência o Município de São Félix do Araguaia-MT.

Tabela 1 


\begin{tabular}{|l|l|l|l|l|l|l|l|}
\hline Localidade & Município & $\begin{array}{l}\text { Atividade geradora } \\
\text { do conflito }\end{array}$ & $\begin{array}{l}\text { Povos } \\
\text { indígenas } \\
\text { atingidos }\end{array}$ & $\begin{array}{l}\text { Terra } \\
\text { Indígena }\end{array}$ & $\begin{array}{l}\text { Outras } \\
\text { populações }\end{array}$ & $\begin{array}{l}\text { Impactos } \\
\text { socioambientais }\end{array}$ & $\begin{array}{l}\text { atualização } \\
\text { site }\end{array}$ \\
\hline MT & $\begin{array}{l}\text { São Felix do } \\
\text { Araguaia }\end{array}$ & $\begin{array}{l}\text { Atuação de entidades } \\
\text { governamentais }\end{array}$ & Xavante & Sangradouro & Não & $\begin{array}{l}\text { Falta / irregularidade } \\
\text { na demarcação de } \\
\text { território tradicional }\end{array}$ & 2009 \\
\hline
\end{tabular}

Fonte: Os Autores, a partir da sistematização de dados do Mapa de Conflitos da FIOCRUZ (2020a).

Abaixo, segue transcrição de trecho constante na ficha correspondente que possui como título "MT - Precariedade do atendimento à saúde indígena, terceirização, falta de estrutura e inconstância do dever do Estado já levou à morte muitas crianças Xavante”:

Além da questão fundiária, muito intensa em algumas das terras indígenas, os Xavante sofrem hoje com o precário atendimento da Fundação Nacional de Saúde (Funasa) em relação aos programas de promoção da saúde indígena. Doenças como tuberculose, pneumonia e leishmaniose avançam sobre essas áreas. A cobertura de vacinação ainda é incipiente e muitas vezes as equipes médicas encarregadas da saúde dessa população sequer possuem transporte que possibilite a visita às aldeias ou o translado dos casos mais graves para hospitais da região. Os conflitos com fazendeiros pela posse de suas terras muitas vezes resultam em situações de extrema precariedade e miséria, o que resulta em situações de insegurança alimentar e casos de desnutrição. Por tudo isso, a mortalidade infantil ainda é alta entre os Xavante. Além de conviverem com programas equivocados de promoção da saúde indígena, eles lutam hoje para garantir uma administração regional atenta a suas demandas, razão pela qual é comum indicarem chefes do DSEI Xavante ou exigir a saída de funcionários que eles consideram inaptos para o cargo. Tudo isso, em meio a escândalos envolvendo a contratação de empresas terceirizadas, pela Funasa, para a execução dos referidos programas (FIOCRUZ, 2020b).

[sem grifo no original]

Da leitura da ficha correspondente, percebe-se que não há discussão sobre a questão territorial, mas tão somente uma constatação da preocupação com os elevados índices de falecimento de crianças indígenas Xavantes por falta de cuidados básicos de saúde. Deste modo, em casos como este, além das demais categorias previamente existentes, foi criada uma nova categoria denominada "Falta de atendimento à Saúde indígena".

$\mathrm{Na}$ Tabela 1, abaixo, consta uma relação com principais "Atividades geradoras de conflito", separadas por região brasileira: 
Tabela 2

\begin{tabular}{|c|c|c|c|c|c|c|}
\hline & Brasil & Sul & Sudeste & Centro Oeste & Nordeste & Norte \\
\hline $\begin{array}{l}\text { Atuação de entidades } \\
\text { governamentais }\end{array}$ & 106 & 13 & 10 & 17 & 24 & 42 \\
\hline $\begin{array}{l}\text { Barragens e } \\
\text { hidrelétricas }\end{array}$ & 49 & 7 & 5 & 12 & 6 & 19 \\
\hline Monoculturas & 46 & 3 & 4 & 15 & 14 & 10 \\
\hline $\begin{array}{l}\text { Políticas públicas e } \\
\text { legislação ambiental }\end{array}$ & 37 & 4 & 7 & 2 & 10 & 14 \\
\hline Madeireiras & 34 & 1 & 0 & 9 & 3 & 21 \\
\hline $\begin{array}{l}\text { Mineração, garimpo e } \\
\text { siderurgia }\end{array}$ & 32 & 3 & 4 & 4 & 4 & 17 \\
\hline $\begin{array}{l}\text { Atuação do Judiciário } \\
\text { e/ou do Ministério } \\
\text { Público }\end{array}$ & 26 & 4 & 3 & 8 & 6 & 5 \\
\hline Pecuária & 25 & 1 & 3 & 7 & 4 & 10 \\
\hline $\begin{array}{l}\text { Hidrovias, rodovias, } \\
\text { ferrovias, } \\
\text { complexos/terminais } \\
\text { portuários e } \\
\text { aeroportos }\end{array}$ & 25 & 2 & 3 & 5 & 2 & 13 \\
\hline $\begin{array}{l}\text { Falta de atendimento } \\
\text { à Saúde indígena }\end{array}$ & 19 & 0 & 0 & 1 & 4 & 14 \\
\hline $\begin{array}{l}\text { Minerodutos, } \\
\text { oleodutos e } \\
\text { gasodutos }\end{array}$ & 11 & 1 & 1 & 3 & 1 & 5 \\
\hline $\begin{array}{l}\text { Especulação } \\
\text { imobiliária }\end{array}$ & 9 & 2 & 1 & 0 & 3 & 3 \\
\hline Agrotóxicos & 9 & 1 & 1 & 5 & 0 & 2 \\
\hline $\begin{array}{l}\text { Implantação de áreas } \\
\text { protegidas }\end{array}$ & 7 & 4 & 0 & 0 & 0 & 3 \\
\hline Indústria do turismo & 5 & 1 & 2 & 0 & 0 & 2 \\
\hline $\begin{array}{l}\text { Atividades } \\
\text { pesqueiras, } \\
\text { aquicultura, } \\
\text { carcinicultura e } \\
\text { maricultura }\end{array}$ & 5 & 0 & 0 & 0 & 1 & 4 \\
\hline $\begin{array}{l}\text { Indústria química e } \\
\text { petroquímica }\end{array}$ & 4 & 0 & 1 & 0 & 1 & 2 \\
\hline $\begin{array}{l}\text { Energia e radiações } \\
\text { nucleares }\end{array}$ & 3 & 0 & 0 & 0 & 0 & 3 \\
\hline $\begin{array}{l}\text { Extrativismo } \\
\text { comercial }\end{array}$ & 2 & 1 & 0 & 0 & 0 & 1 \\
\hline Construção civil & 2 & 0 & 1 & 0 & 0 & 1 \\
\hline $\begin{array}{l}\text { Transposição de } \\
\text { bacias hidrográficas }\end{array}$ & 2 & 0 & 0 & 0 & 2 & 0 \\
\hline Indústrias outras & 2 & 0 & 0 & 0 & 1 & 1 \\
\hline $\begin{array}{l}\text { Linhas de } \\
\text { transmissão }\end{array}$ & 2 & 0 & 0 & 0 & 0 & 2 \\
\hline Outros & 6 & 0 & 0 & 1 & 2 & 3 \\
\hline
\end{tabular}

Fonte: Os Autores, a partir da sistematização de dados do Mapa de Conflitos da Fiocruz (2020a). 
É relevante demonstrar que, a nível Brasil, dos 166 conflitos planilhados, 106 deles apresentam como "Atividade geradora de conflito" a "Atuação de entidades governamentais". As categorias "Barragens e Hidrelétricas" (49 ocorrências) e "Monoculturas" (46 ocorrências) apresentam, cada uma, quase um terço dos casos de conflitos.

Também são relevantes a quantidade de ocorrências de "Políticas públicas e legislação ambiental" (37 ocorrências), "Madeireiras" (34 ocorrências), "Mineração, garimpo e siderurgia" (32 ocorrências), "Atuação do Judiciário e/ou do Ministério Público" (26 ocorrências), "Pecuária" (25 ocorrências), "Hidrovias, rodovias, ferrovias, complexos/terminais portuários e aeroportos" (25 ocorrências) e "Falta de atendimento à Saúde indígena" (19 ocorrências) - categoria nova criada pelos autores, conforme explicado acima. Problemas envolvendo a precária situação dos atendimentos à saúde indígena ${ }^{5}$ somam $11,45 \%$ do total, portanto.

Os casos com incidência de apenas uma ocorrência, foram categorizadas como Outros (Energia eólica, Termoelétrica, Carvoarias, Petróleo e gás-exploração, Ação missionária e Narcotráfico).

Note-se, contudo, que dentre estas, as duas primeiras integram a matriz energética brasileira (atualmente separada em Usinas Hidrelétricas - UHE, Pequenas Centrais Hidrelétricas - PCH, Usinas Termoelétricas - UTE, Usinas Fotovoltaicas -UFV, Usinas Eólicas - EOL, e Linhas de transmissão - LT). Somando-se as incidências de casos envolvendo tal matriz ("Barragens e Hidrelétricas" 49 ocorrências, "Energia e radiações nucleares" 3 ocorrências, "Linhas de transmissão" 2 ocorrências, "Energia eólica" 1 ocorrência e "Termoelétrica" 1 ocorrência), observa-se que o impacto do Setor Elétrico Brasileiro (SEB) sobre os povos indígenas é significativo, posto alcançar o patamar de 37,73\%.

O planejamento do Setor Elétrico Brasileiro, vinculado ao Ministério de Minas e Energia-MME, efetua o levantamento da demanda futura de energia elétrica, segundo critérios de continuidade, segurança e confiabilidade, sendo necessário elaborar e analisar as alternativas de implantação de novas usinas de geração de energia e linhas de transmissão, considerando variáveis tecnológicas, econômicas e socioambientais.

\footnotetext{
${ }^{5}$ Em meio a uma pandemia mundial (COVID-19), a melhoria das condições de saúde indígena torna-se prioridade. Em ação interposta pela Articulação dos Povos Indígenas do Brasil - APIB, em meados de 2020, houve concessão de liminar pelo Supremo Tribunal Federal impondo ao governo federal o dever de implementar medidas emergenciais para combater a pandemia, dentre as quais ressalta-se a contenção de invasores em terras indígenas os quais podem disseminar o vírus, gerando, inclusive, genocídio aos indígenas isolados (Instituto Socioambiental, 2020a).
} 
Entretanto, no Brasil, percebe-se que os impactos socioambientais provocados por empreendimentos são, muitas vezes, aferidos e levados em consideração em momento posterior ao planejamento das ações, posto que o próprio procedimento de licenciamento ambiental prevê a consulta pública num momento tardio do procedimento, inviabilizando uma construção conjunta de planejamento entre as comunidades atingidas e o empreendedor (BARRETO, 2020).

Analisando os dados constantes no Gráfico 1 (abaixo), nota-se que a "Atuação de entidades governamentais" aparece como principal atividade causadora de conflito em todas as macrorregiões.

Gráfico 1

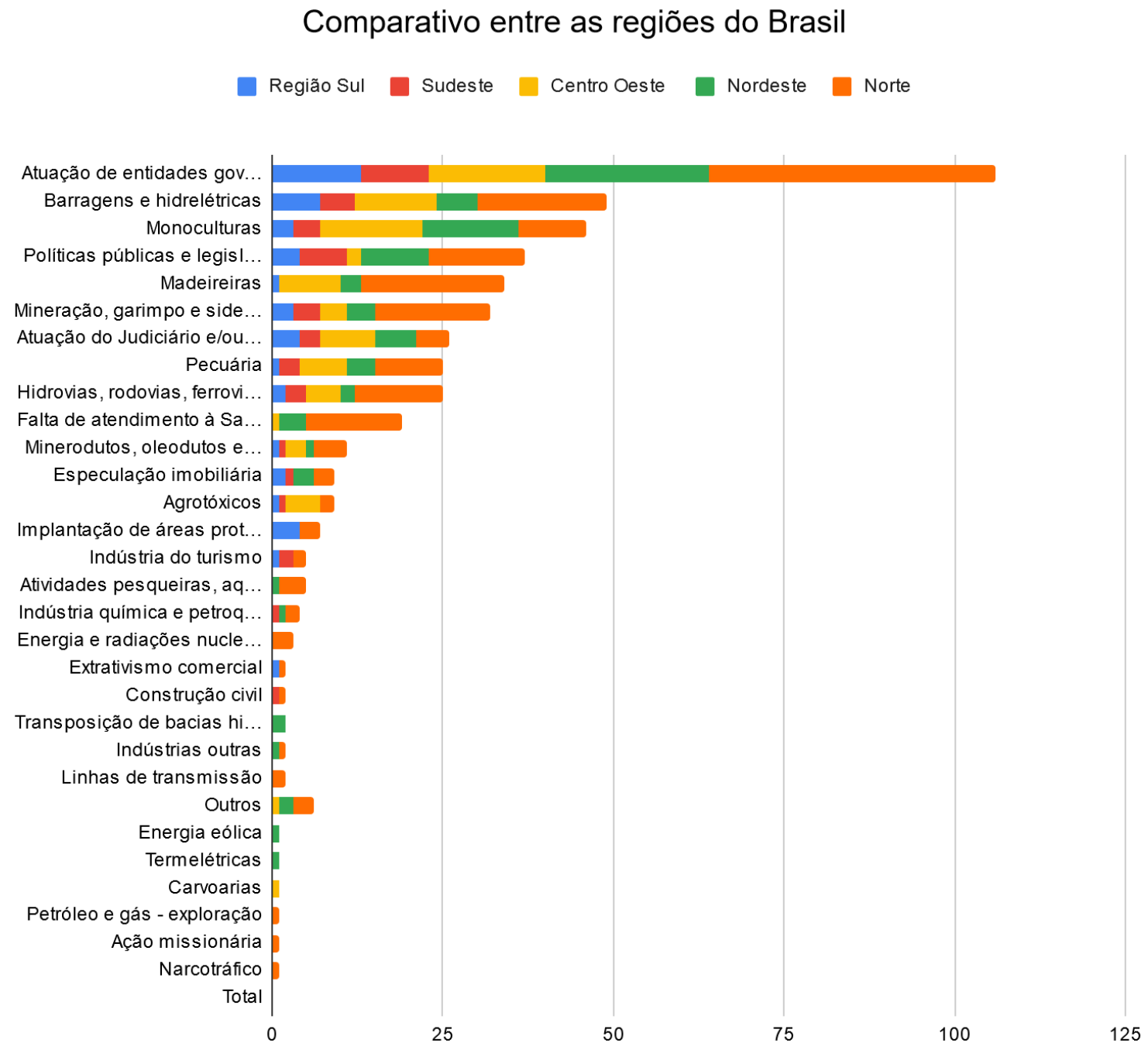

Fonte: Os Autores, a partir da sistematização de dados do Mapa de Conflitos da FIOCRUZ (2020a). 
O Gráfico 2, abaixo, foi elaborado com base nas principais atividades causadoras de conflito, a nível Brasil, considerando o percentual de incidência por atividade. Neste outro formato novamente é possível visualizar a atuação de entidades governamentais com maior percentual de incidência.

\section{Gráfico 2}

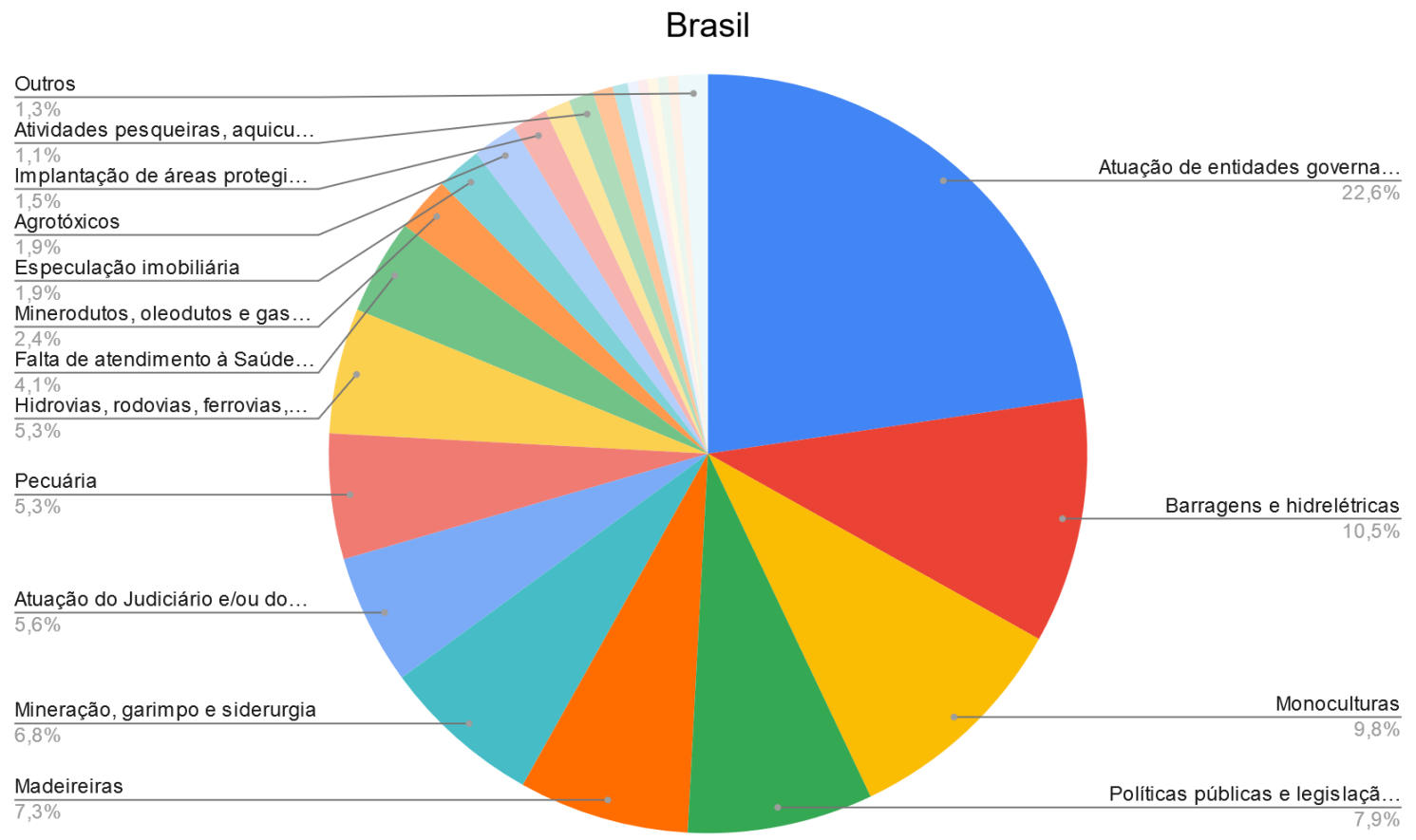

Fonte: Os Autores, a partir da sistematização de dados do Mapa de Conflitos da FIOCRUZ (2020a).

Os demais, variam de acordo com as macrorregiões; assim, destacou-se as principais ocorrências em cada uma delas. Na região Sul, os conflitos envolvem principalmente "Barragens e hidrelétricas" (14,6\% dos conflitos). 
Gráfico 3

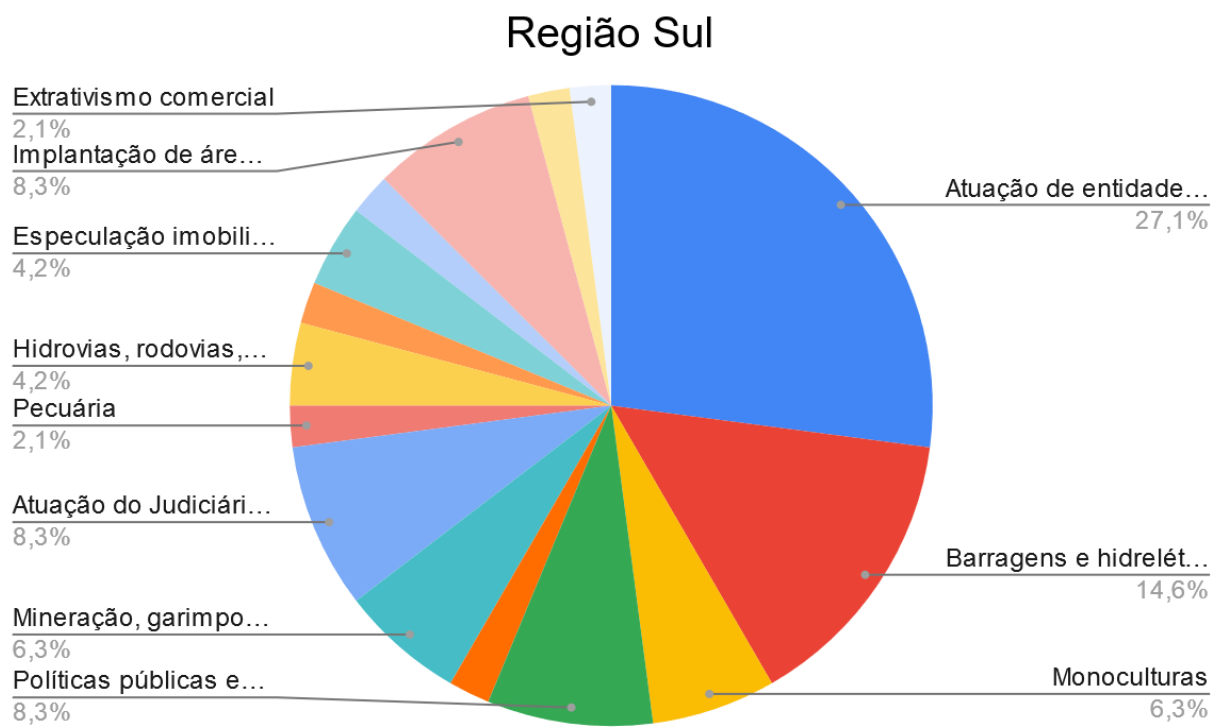

Fonte: Os Autores, a partir da sistematização de dados do Mapa de Conflitos da FIOCRUZ (2020a).

$\mathrm{Na}$ região Sudeste, observa-se que a categoria "Políticas públicas e legislação ambiental" é responsáveis por $15,2 \%$ dos conflitos. É relevante destacar que parte destes conflitos decorre da criação de áreas de proteção integral (seguindo as diretrizes do Sistema Nacional de Unidades de Conservação - SNUC, Lei no 9.985/2000), que exclui a permanência de populações tradicionais no interior de tais ambientes.

Gráfico 4

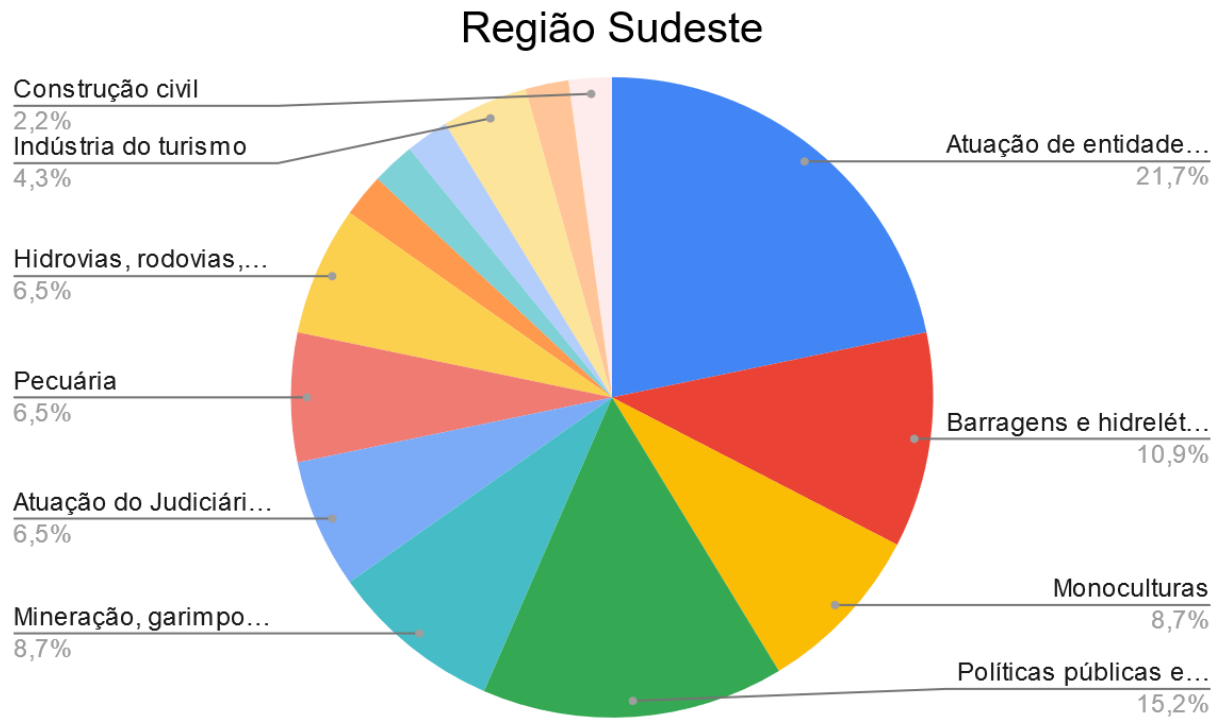

Fonte: Os Autores, a partir da sistematização de dados do Mapa de Conflitos da FIOCRUZ (2020a). 
Na região Centro-Oeste, observa-se grande quantidade de conflitos decorrentes de "Monoculturas" (16,9\% dos conflitos), "Barragens e hidrelétricas" (13,5\% dos conflitos) e "Madeireiras" (10,1\% dos conflitos).

Gráfico 5

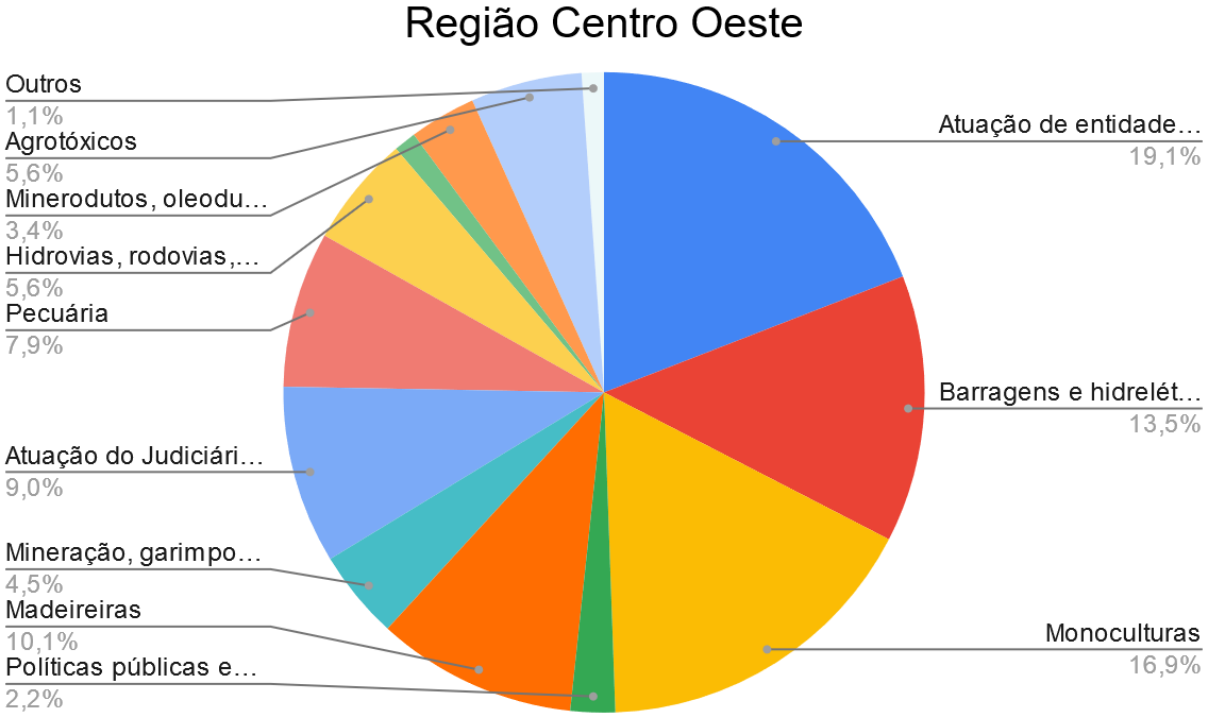

Fonte: Os Autores, a partir da sistematização de dados do Mapa de Conflitos da FIOCRUZ (2020a).

Na região Nordeste, destacam-se "Monoculturas" (15,9\% dos conflitos" e "Políticas públicas e legislação ambiental" (11,4\% dos conflitos).

Gráfico 6

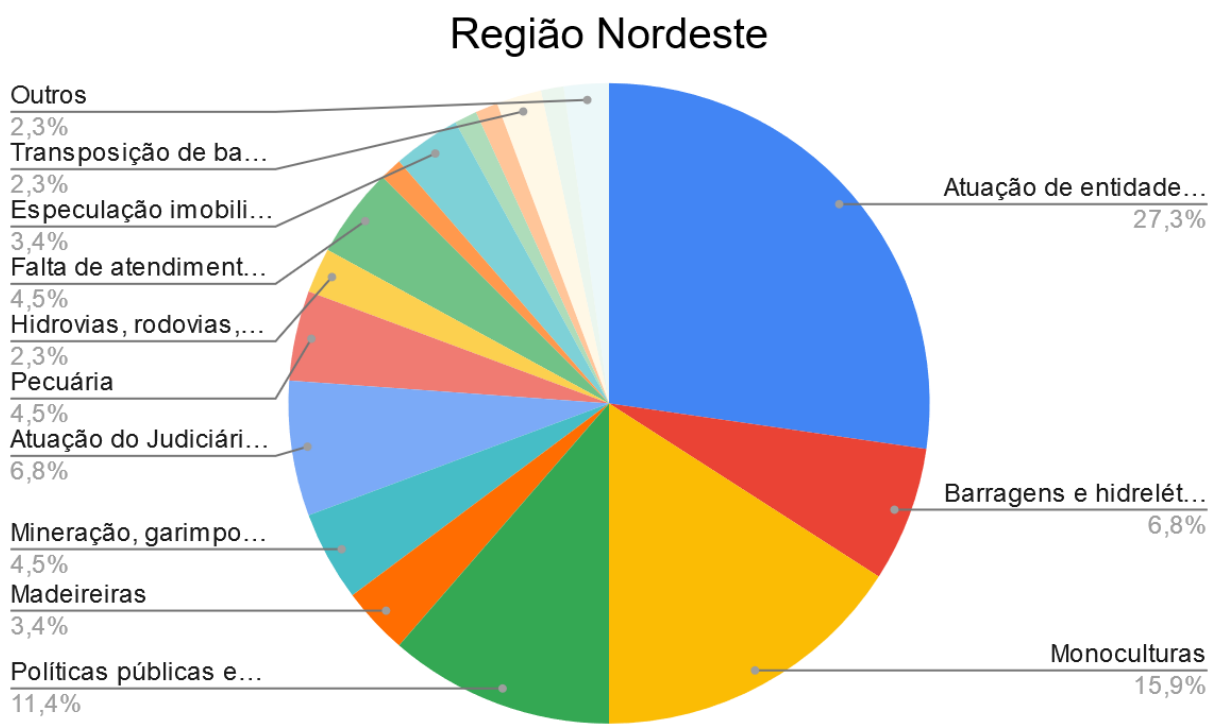


Fonte: Os Autores, a partir da sistematização de dados do Mapa de Conflitos da FIOCRUZ (2020a).

E, por fim, na região Norte, diferentemente das demais regiões, destacam-se "Madeireiras" (10,7\% dos conflitos), "Barragens e Hidrelétricas" (9,6\% dos conflitos), seguido de "Mineração, garimpo e siderurgia" ( $8,6 \%$ dos conflitos $)$.

\section{Gráfico 7}

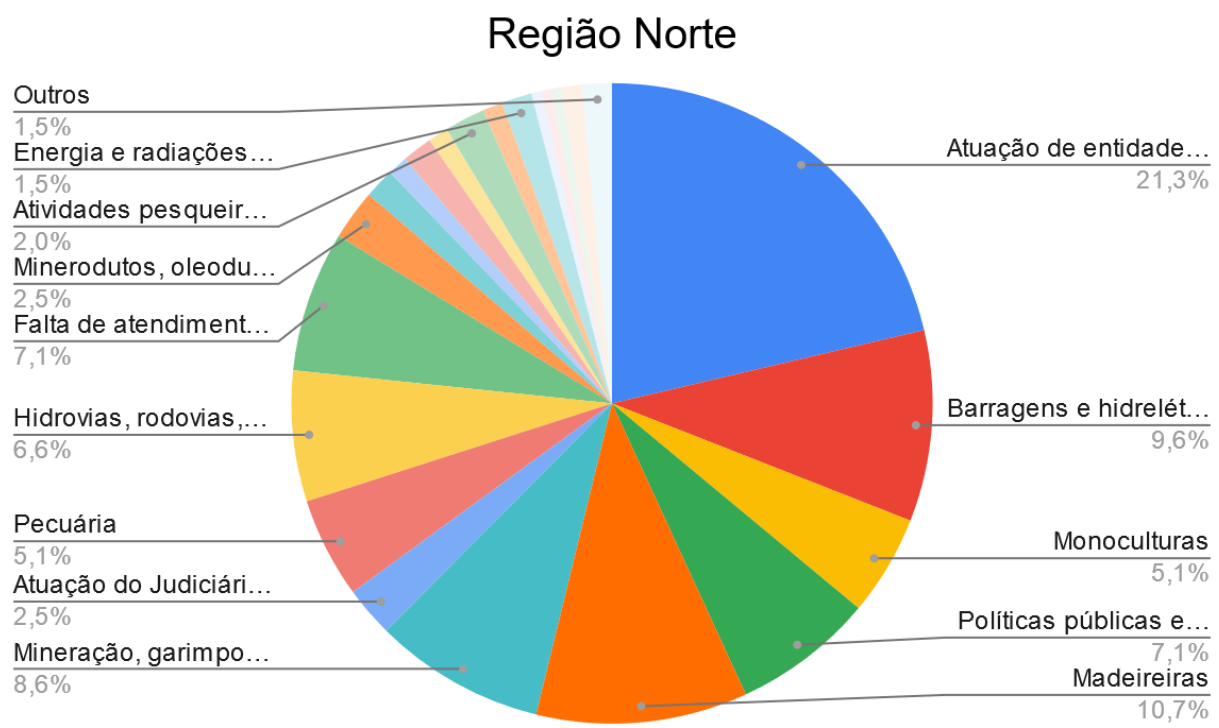

Fonte: Os Autores, a partir da sistematização de dados do Mapa de Conflitos da FIOCRUZ (2020a).

Retornando a análise global dos dados (nível Brasil), têm-se que o neoextrativismo apresenta impacto bastante significativo sobre as terras indígenas: 50,60\% ("Madeireiras" 34 ocorrências, "Mineração, garimpo e siderurgia" 32 ocorrências, "Mineroduto, oleoduto e gasoduto" 11 ocorrências, "Atividades pesqueiras, aquicultura, carnicultura e maricultura" 5 ocorrências e "Extrativismo comercial" 2 ocorrências).

O agronegócio, por sua vez, representa 42,77\% das ocorrências ("Monoculturas" 46 ocorrências; e "Pecuária" 25 ocorrências).

Assim, como explicado por FLORIANI (2020, p. 296-297), “a produção de desigualdades sociais resulta e reforça ao mesmo tempo o quadro da formação social capitalista periférica no contexto de modernidades múltiplas". Isto porque o modelo existente, vicioso e excludente, busca o constante crescimento econômico. E este, calcado na produção e exportação de commodities pelas atividades neoextrativistas e pelo agronegócio, acaba gerando os impactos socioambientais negativos nas populações mais vulneráveis, como se demonstra no estudo ora apresentado. 


\section{A racionalidade econômica imperante na sociedade brasileira}

Um segundo tópico necessário no presente trabalho diz respeito à racionalidade existente neste modelo de desenvolvimento instaurado no Brasil. Conforme dados constantes no site do Instituto Socioambiental (2020), houve uma impactante redução na identificação, declaração e homologação de terras indígenas a partir de 2019. Abaixo, é possível observar uma retrospectiva histórica de 2011 a 2020 (até setembro 2020).

Gráfico 8

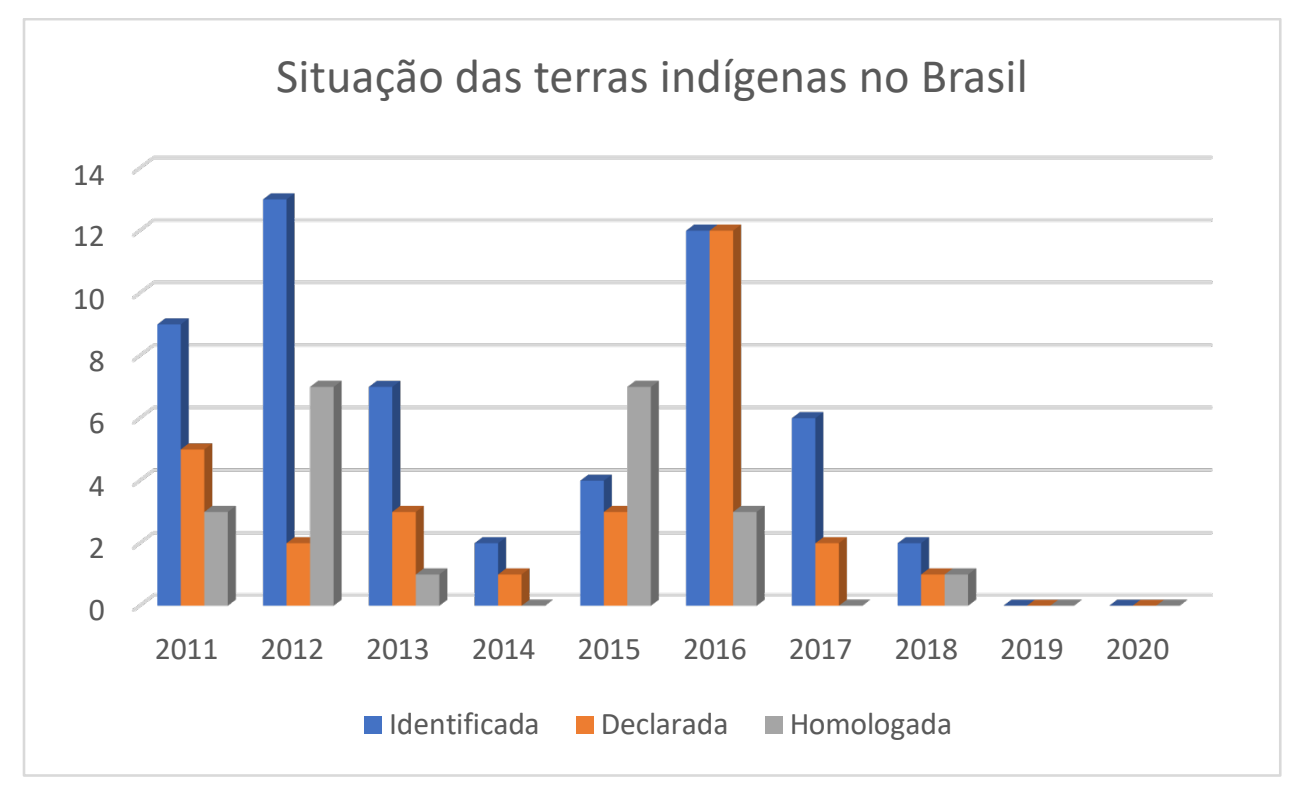

Fonte: Instituto Socioambiental (2020), elaboração própria.

Este levantamento é bastante significativo para demonstrar os efeitos reais desta racionalidade econômica existente no Brasil. Analisando o gráfico acima, percebe-se que durante todos os governos anteriores, ainda que moroso, havia um interesse estatal na regularização das terras indígenas; tal fato, contudo, deixou de existir a partir de 2019, quando os processos de identificação, declaração e homologação foi interrompido. Tal realidade não decorre de mudanças no arcabouço legislativo, que permanece praticamente inalterada desde 1988, mas sim da grande pressão exercida pelos grupos ligados ao agronegócio (TERRA DE DIREITOS, 2015, p. 10).

Ademais, sabe-se que no Brasil o acesso à terra é caracterizado pela desigualdade, e a estrutura fundiária nacional é marcada pelo alto número de latifúndios que utilizam grandes extensões territoriais para a produção de suas lavouras em monocultura (VILAS BOAS, 2017, 
p. 191). Conforme informações do IBGE (2020b e 2020c), Censo Agropecuário, apenas 23\% da área de todos os estabelecimentos agropecuários do país correspondem à agricultura familiar. Por região brasileira, nota-se uma grande variedade: enquanto o Centro-Oeste possui $5,5 \%$ de agricultura familiar em toda a sua extensão territorial, o Nordeste possui $46,6 \%$; as outras três regiões, em torno de 15\% cada uma (15,4 Nordeste; 16,5 Sudeste; e 16,0 Sul).

A produção em latifúndios e monocultura, mesmo gerando menos lucro por hectare em comparação com os sistemas agroflorestais (GLOBO RURAL, 2020), possui concentração de capital nas mãos de poucos indivíduos.

A Figura 2, abaixo, foi extraída do IBGE (2020a) - Censo Agropecuário 2006 e demonstra a evolução das áreas utilizadas para o plantio de determinados tipos de produtos (café, cana-de-açúcar, milho em grão, soja em grão e trigo em grão).

\section{Gráfico 9}

Área colhida por tipo de produto, 1950 - 2006

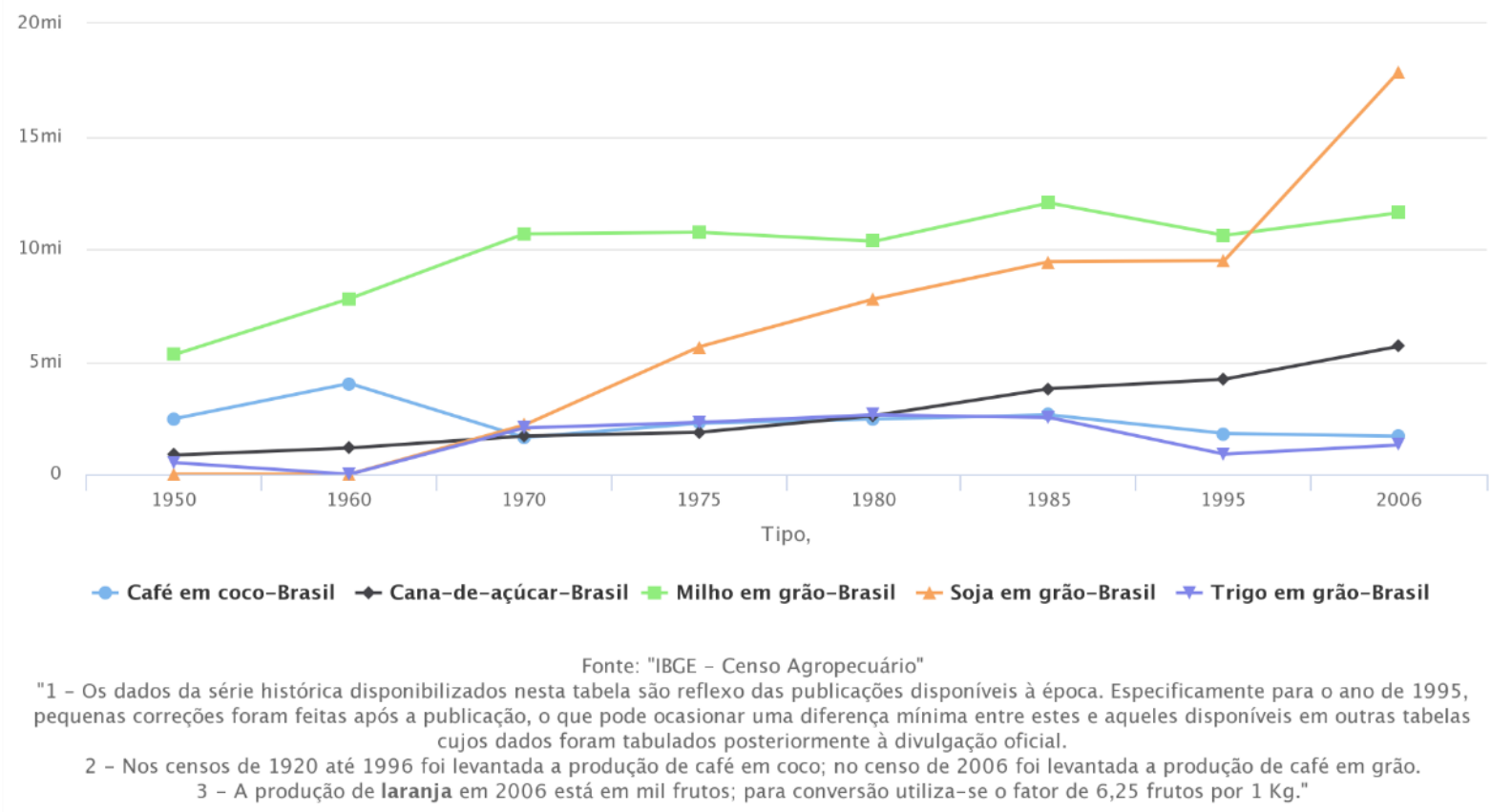

Fonte: IBGE (2020a), Série Histórica 1950-2006

O Gráfico 10, abaixo, demonstra o percentual de exportação, do Brasil, no período de 1945 e 2007. 
Gráfico 10

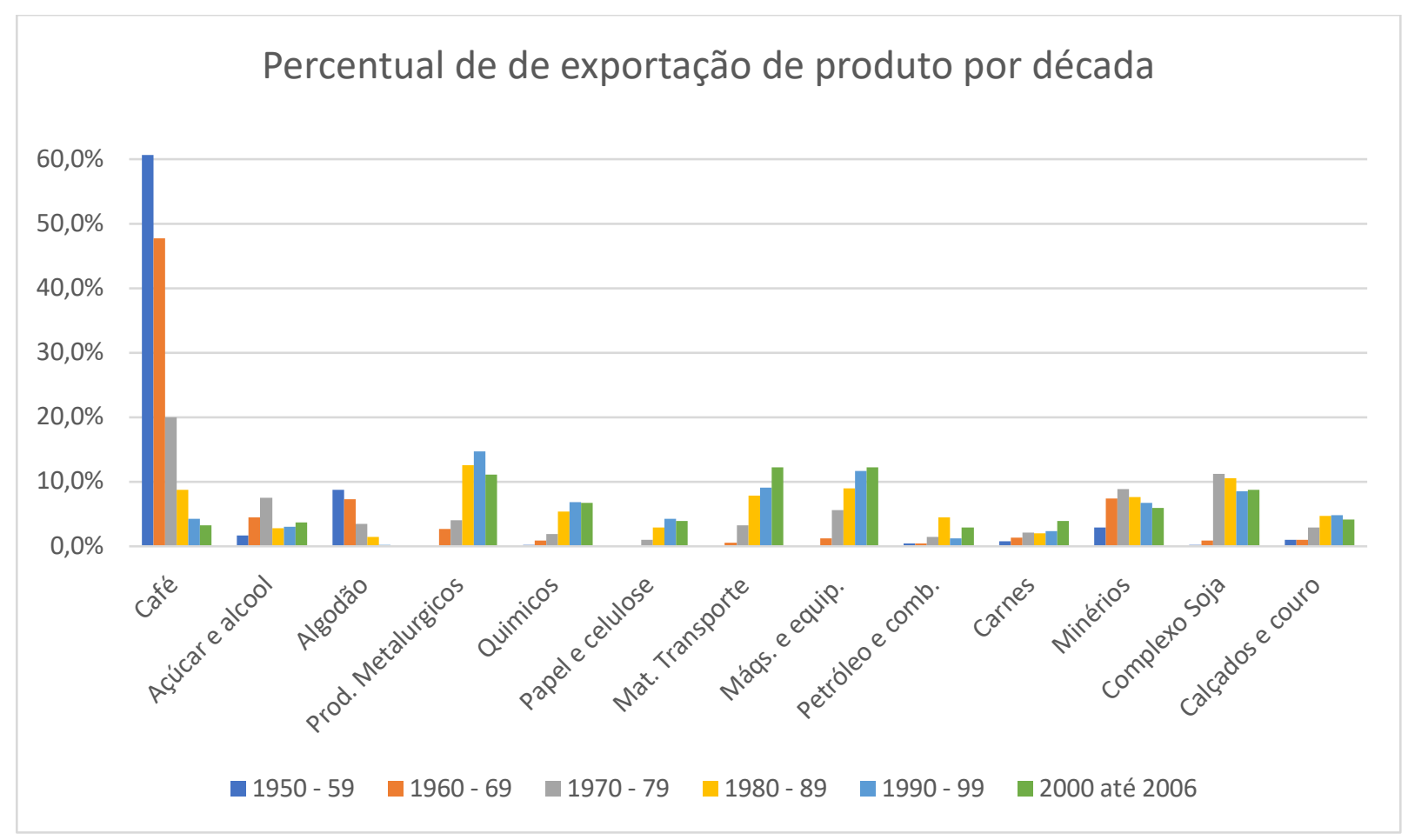

Fonte: Os Autores, a partir da sistematização de dados do IBGE (2020a)

Comparando os dados do Gráfico 9 com os dados do Gráfico 10, que abarcam períodos históricos equivalentes, é possível perceber que o café, a cana-de-açúcar, e o grão de soja são produtos que se mantém na exportação brasileira durante todo este período, com significativo impacto percentual. O milho, presente na Gráfico 9, serve, em grande medida, para alimentar a agropecuária nacional (BRASIL, 2020a), favorecendo a exportação de carnes, calçados e couros (Gráfico 8).

Da análise dos dados, percebe-se a produção nacional de tais produtos está voltada majoritariamente para o mercado externo. BELLUZZO et. al. (2014) argumenta, por exemplo, que por meio de novos métodos e técnicas de extração de minérios, ao invés destes caminharem para a exaustão estariam se expandindo (BELLUZZO et. al., 2014, capítulo VI). Na realidade, os minérios estão sim caminhando para a exaustão dos recursos, mas as novas tecnologias têm oportunizado a descoberta de novas reservas as quais localizam-se, em grande medida, sob território indígena ou em área de biomas naturais. Os conflitos descritos no tópico precedente ratificam esta realidade.

Ademais, a modernidade / colonialidade foi configurada pela superação do espaçotempo e sua relação com o pensamento, ligando a história de duas geografias (da Europa e das Américas) de forma hierarquizada. 
O extrativismo mineiro é, então, um projeto concebido em 1492 cuja execução foi dar existência ao ser histórico americano para manter o "velho mundo" vivo, através do envio da natureza e a sujeição cultural do "novo mundo" à história teleológica universal governado e guiado pela Europa. Assim, a mineração é, então, a expressão de uma nova materialidade própria com a criação do sistema moderno / colonial (ABAD RESTREPO, 2018, p. 58).

[sem grifo no original]

Ainda que o autor esteja se referindo especificamente à mineração [extrativismo mineral], pode-se estender esta visão a toda lógica extrativista existente não apenas no Brasil, mas em toda a América Latina.

Quanto ao agronegócio, BELLUZZO et. al. (2014, p. 18) defende que a competitividade agrícola no país é resultado de uma elevada eficiência produtiva, gerando baixo custo de produção em açúcar, álcool, soja, milho, carne bonina, dentre outros (BELLUZZO et. al., 2014, p. 18). Deste modo, “o Brasil é responsável por mais de 30\% das exportações mundiais de soja, mais de $40 \%$ de açúcar e mais de $80 \%$ do mercado exportador de suco de laranja" (BELLUZZO et. al., 2014, p. 44).

A existência de uma "crença" de que a única solução econômica possível em nosso sistema produtivo seria a exportação de produtos provenientes do neoextrativismo e do agronegócio, pois estes manteriam a balança comercial favorável, gera impactos significativos ao desconsiderar sistemas produtivos integrados à natureza, como os sistemas de agroflorestas, de cultivo de orgânicos, de agricultura familiar e pequena propriedade rural, dentre outros. Estes sistemas, mesmo gerando maior renda por hectare e realizando uma conservação do meio ambiente, são exceção no Brasil, que reforçam pela propaganda oficial e pela mídia sua supremacia em relação aos aspectos socioambientais relevantes das práticas voltadas à produção de alimentos em base à agricultura familiar e às estratégias agroecológicas.

Neste sentido, é importante destacar que a colonização da América Latina foi marcada pela escravidão e pela destruição da natureza (SOUZA FILHO, PRIOSTE, 2017, p. 2905); é esta mesma lógica de destruição que se mantém ainda hoje. O colonialismo brasileiro, desde o início, estava preocupado na usurpação das terras descobertas e em suas potenciais riquezas. $\mathrm{O}$ regime das sesmarias estava totalmente voltado para a concessão de terras e à capacidade de arregimentar trabalho para produzir excedentes que pudessem ser remetidos para a metrópole Portugal. Todas as terras eram pertencentes ao Rei de Portugal e sua benevolência era dirigida 
aos indígenas amigos que aprendessem a ser bons trabalhadores e cristãos (SOUZA FILHO, PRIOSTE, 2017, p. 2908-2909).

Quase todos os povos indígenas brasileiros resistiram neste processo, e inúmeros massacres ocorreram na chamada "atração" indígena (FREIRE, 2005, p. 32). Contudo, a metrópole desde cedo compreendeu que a guerra conta os indígenas estava ligada à usurpação de seus territórios, e não à captura de mão de obra (SOUZA FILHO, PRIOSTE, 2017, p. 29082910). Tal lógica foi gerando a devastação da natureza pelo avanço do capitalismo agrário através da invisibilização dos povos da floresta (SOUZA FILHO, 2015, p. 62-66).

Neste aspecto, SOUZA FILHO (2015, p. 66) explica que ao lado da política integracionista existente na América Latina há uma ideologia de negação da existência dos povos indígenas e tribais; ao se negar a existência de tais povos, se nega a ocupação que as pessoas fazem da terra o que, imediatamente, fica passível de esvaziamento e usurpação.

Deste modo, sugere-se que a estagnação no processo demarcatório de terras indígenas está vinculada com uma racionalidade econômica existente no Brasil que fomenta o neoextrativismo e o agronegócio, e é contrária aos interesses dos povos originários; os conflitos socioambientais existentes em terras indígenas, conforme demonstrado no tópico precedente, seria tão somente uma consequência de tal lógica econômica.

\section{Considerações Finais}

Conforme apresentado ao longo do texto, a atuação do poder público, seja pela omissão ou pela forma de intervenção sobre as terras indígenas, é o principal fator que está na base da geração de conflitos, ocorrendo em 63,86\% dos casos. Outros impactos significativos dizem respeito ao neoextrativismo que, somado, chega a 50,60\% das ocorrências; o agronegócio que, somado, representa $42,77 \%$ das ocorrências, e os impactos da matriz energética brasileira que, igualmente somado, atinge $37,74 \%$ dos conflitos ${ }^{6}$.

A leitura das fichas de conflitos detalhadas existente no Mapa de Conflitos (FIOCRUZ, 2020a) foi importante para perceber que, independentemente do tipo de "Atividade geradora de conflito", a grande preocupação das populações indígenas é a delimitação territorial (através dos procedimentos administrativos próprios), seguido de manutenção de território (inclusive contra investidas do próprio poder público).

\footnotetext{
${ }^{6}$ Note-se que o somatório é superior a $100 \%$; entretanto, conforme explanado na metodologia, os agentes causadores sobrepõem-se ou são transversais aos demais casos registrados, podendo existir mais de um tipo de agente responsável em cada ocorrência identificado no Mapa de Conflitos (FIOCRUZ, 2020a).
} 
Nas terras indígenas nas quais há demarcação e posse efetiva (e sem ameaças territoriais), os conflitos socioambientais passam a se relacionar com demandas sobre um efetivo atendimento à saúde e à educação (respeitando a diversidade sociocultural existente).

Por outro lado, a pandemia mundial (COVID-19) ratifica informação de que as ameaças territoriais impactam nas condições de saúde das populações indígenas, especialmente porque o invasor pode ser portador de doenças extremamente danosas (como é o caso do COVID-19).

Percebe-se, por fim, que a análise de dados do Mapa de Conflitos apresenta-se como um instrumento efetivo para reflexões e análises das racionalidades econômica (de mercado) e socioambiental, reforçando os limites estruturantes da sociedade capitalista, e seus impactos sobre as populações mais vulneráveis (no caso analisado, as populações indígenas) e também sobre o meio ambiente (através de uma estrutura de mercantilização da natureza).

Ressalte-se que este diagnóstico sobre os principais casos associados aos conflitos em territórios indígenas merecerá aprofundamento futuro, levando em conta os tipos de respostas dadas pelos atores envolvidos nesses conflitos, especialmente pelas populações indígenas e suas formas jurídicas e políticas mobilizadas como estratégia de resistência.

\section{Referências}

ABAD RESTREPO, C. Descolonización y la ampliación geopolítica de las resistencias contra-extractivas en/desde Améria Latina /Abya Yala. Tese de doutorado em Geografia. UFPR, 2018.

ALBERGONI, L.; PELAEZ, V. Da revolução verde à agrobiotecnologia: ruptura ou continuidade de paradigmas? Revista de Economia, Curitiba, v. 33, n. 1, p. 31-53, jan./jun. 2007.

BARRETO, N.L. Democracia e Direitos Socioambientais no Brasil: legados autoritários e desigualdades políticas na separação entre modelos de desenvolvimento e meio ambiente. 2020. Tese (Pós-graduação em Meio Ambiente e Desenvolvimento) - Universidade Federal do Paraná.

BECK, U. Sociedade de risco. Ruma a uma outra modernidade. Trad. Sebastião Nascimento. 2. ed. São Paulo: Editora 34, 2011.

BELLUZZO, L.G. de M; FRISCHTAK, C.R.; LAPLANE, M (Orgs.) Produção de Commodities e Desenvolvimento Econômico. Campinas: UNICAMP. Instituto de Economia, 2014, 126 p.

BRASIL. Ministério da Agricultura, Pecuária e Abastecimento. Empresa Brasileira de Pesquisa Agropecuária - EMBRAPA, 2005-2010. Atividades Econômicas Cultivos Milho (Mercado e Comercialização). Disponível em: https://www.agencia.cnptia.embrapa.br/gestor/territorio_sisal/arvore/CONT000fck180cd02wx 
5eo0a2ndxy8x2s1 to.html\#: :text=Destino $\% 20 \mathrm{da} \% 20 \mathrm{Produ} \% \mathrm{C} 3 \% \mathrm{~A} 7 \% \mathrm{C} 3 \% \mathrm{~A} 3 \mathrm{o}$, parte $\% 20 \mathrm{e}$ $\% 20$ ao $\% 20$ consumo\%20humano. Acesso em: 06 out. 2020a.

BRASIL. Ministério da Economia. Balança comercial brasileira: Semanal. Disponível em http://www.mdic.gov.br/comercio-exterior/estatisticas-de-comercio-exterior/balancacomercial-brasileira-semanal. Acesso em: 14 ago. $2020 \mathrm{~b}$.

COMPRE RURAL. Brasil cumprirá o seu papel e produzirá $40 \%$ a mais de alimentos de origem animal até 2050, como pede FAO. Disponível em

https://www.comprerural.com/confirmado-brasil-sera-celeiro-do-mundo/. Acesso em 14 ago. 2020 .

ESCOBAR, A. O lugar da natureza e a natureza do lugar: globalização ou pósdesenvolvimento. In: LANDER, E. (org.). A Colonialidade do saber: eurocentrismo e ciências sociais, Perspectivas latino-americanas. Buenos Aires: CLACSO, 2005, p. 133-168.

FLORIANI, D. Questão Ambiental na Contemporaneidade: conflitos socioambientais, garantias constitucionais e a efetividade das políticas públicas em debate. [Entrevista concedida a] MESQUISA, B.A. Revista de Políticas Públicas, p. 281-301, 2020.

FREIRE, C.A.R. Sagas Sertanistas: práticas e representações do campo indigenista no século XX. Tese de doutorado em Antropologia Social. UFRJ, 2005.

FUNDAÇÃO OSWALDO CRUZ - FIOCRUZ. Mapa de conflitos envolvendo injustiça ambiental e saúde no Brasil. Disponível em:

http://www.conflitoambiental.icict.FIOCRUZ.br. Acesso em: 29 jul. 2020a.

FUNDAÇÃO OSWALDO CRUZ - FIOCRUZ. MT - Precariedade do atendimento à saúde indígena, terceirização, falta de estrutura e inconstância do dever do Estado já levou à morte muitas crianças Xavante. In: (org.). Mapa de conflitos envolvendo injustiça

ambiental e saúde no Brasil. Disponível em:

http://mapadeconflitos.ensp.fiocruz.br/?conflito=mt-precariedade-do-atendimento-a-saudeindigena-terceirizacao-falta-de-estrutura-e-inconstancia-do-dever-do-estado-ja-levou-a-mortemuitas-criancas-xavante. Acesso em: 29 jul. $2020 \mathrm{~b}$.

GLOBO RURAL. Agroflorestas geram mais lucro que soja e gado na Amazônia. Disponível em

https://revistagloborural.globo.com/Noticias/Sustentabilidade/noticia/2020/09/agroflorestasgeram-mais-lucro-que-soja-e-gado-na-amazonia.html. Acesso em 23/03/2021.

IBGE. Censo Agropecuário 2006 - Série Histórica. Disponível em https://www.ibge.gov.br/estatisticas/economicas/agricultura-e-pecuaria/21814-2017-censoagropecuario.html?edicao $=25757 \& \mathrm{t}=$ series-historicas. Acesso em 09/10/2020a.

IBGE. Censo Agropecuário 2017 - Resultados definitivos em Agricultura familiar. Disponível em https://censos.ibge.gov.br/templates/censo agro/resultadosagro/pdf/agricultura familiar.pdf. Acesso em 09/10/2020b.

IBGE. Censo Agropecuário 2017 - Resultados definitivos em Produção. Disponível em https://censos.ibge.gov.br/templates/censo_agro/resultadosagro/pdf/producao.pdf. Acesso em 09/10/2020c. 
Instituto Socioambiental - ISA. STF confirma liminar obrigando governo Bolsonaro a combater Covid-19 entre povos indígenas. Brasil. 5 ago. 2020. Disponível em https://www.socioambiental.org/pt-br/noticias-socioambientais/stf-confirma-liminarobrigando-governo-bolsonaro-a-combater-covid-19-entre-povos-indigenas. Acesso em 14 ago. 2020a.

Instituto Socioambiental - ISA. Brasil sofre derrota internacional e deve apresentar plano para COVID-19 em Terra Indígena Yanomami. Brasil. 21 jul. 2020. Disponível em https:/www.socioambiental.org/pt-br/noticias-socioambientais/brasil-sofre-derrotainternacional-e-deve-apresentar-plano-para-covid-19-em-terra-indigena-yanomami. Acesso em 27 ago. 2020 b.

JAIME, P. e LIMA, A. Uma trajetória antropológica: entrevista com Didier Fassin. Horizontes Antropológicos, Porto Alegre, ano 17, n. 36, p. 257-279, jul./dez. 2011.

LEITE, A.Z.; TUBINHO, N.L.G.; SAUER, S. Políticas Públicas para terra e território: um olhar prospectivo sobre os próximos quatro anos no campo brasileiro. In: B823. Brasil: incertezas e submissões? São Paulo: Fundação Perseu Abramo, 2019.

PORTO, M. F.; PACHECO, T.; LEROY, J. P. (Orgs.). Injustiça ambiental e saúde no Brasil: o mapa de conflitos. Editora FIOCRUZ, 2013.

QUIJANO, A. Colonialidade do poder, eurocentrismo e América Latina. In: A colonialidade do saber: eurocentrismo e ciências sociais. Perspectivas latino-americanas. Buenos Aires, 2005 .

QUIJANO, A. Una crítica constructiva para una sociedad destruída. In: IV Foro Social de las Américas, 2010, Paraguai. Disponível em http://dosuniversos.blogspot.com/2011/04/anibalquijanola-preclaridad.html. Acesso em: 29 nov. 2019.

RAWORTH, K. Economia Donut: uma alternativa ao crescimento a qualquer custo. Rio de Janeiro: Zahar, 2019.

ROCHA, D. F.; PORTO, M.F. A vulnerabilização dos povos indígenas frente ao COVID19: autoritarismo político e a economia predatória do garimpo e da mineração como expressão de um colonialismo persistente. Observatório Covid-19 Fiocruz, 2020. 17 p.

SILVA, L.S. Mato Grosso: Celeiro do Mundo. Um estudo sobre as relações de poder e as implicações nas políticas públicas. Tese de doutorado em Sociologia. UFSCAR, 2020.

SOUZA FILHO, C.F.M. Terra mercadoria, terra vazia: povos, natureza e patrimônio cultural. Revista InSURgência. Brasília, ano 1, v. 1, n. 1, 2015, p. 57-71.

SOUZA FILHO, C.F.M.; PRIOSTE, F. Quilombos no Brasil e direitos socioambientais na América Latina. Rev. Direito \& Práxis. Rio de Janeiro, v. 8, n. .4, 2017, p. 2903-2926. SVAMPA, MARISTELLA. As Fronteiras do Neoextrativismo na América Latina. São Paulo: Editora Elefante, 2019.

TERRA DE DIREITOS. Terra é vida, não mercadoria: direitos e mecanismos nacionais e internacionais. Rio de janeiro / Recife: ActionAid, 2015. Disponível em https://terradedireitos.org.br/wpcontent/uploads/2015/11/Terra \%c3\%a9 Vida n\%c3\%a3o Mercadoria_FINAL.pdf. Acesso em $08 / 10 / 2020$. 
Data de recebimento: 12.12 .2020

Data de aprovação: 18.04.2021 